Article

\title{
Potential COVID-19 Drug Candidates Based on Diazinyl-Thiazol-Imine Moieties: Synthesis and Greener Pastures Biological Study
}

\author{
Sraa Abu-Melha ${ }^{1} \mathbb{D}$, Mastoura Mohamed Edrees ${ }^{1,2} \mathbb{D}$, Musa A. Said ${ }^{3, *}$, Sayed M. Riyadh ${ }^{3,4}$, Nadia S. Al-Kaff 5 \\ and Sobhi M. Gomha $4,6, *$ (D)
}

1 Department of Chemistry, Faculty of Science, King Khalid University, Abha 61413, Saudi Arabia; sabomlha@kku.edu.sa (S.A.-M.); mstorh@kku.edu.sa (M.M.E.)

2 Department of Organic Chemistry, National Organization for Drug Control and Research (NODCAR), Giza 12311, Egypt

3 Department of Chemistry, Faculty of Science, Taibah University, Al-Madinah Al-Munawarah 30002, Saudi Arabia; riyadh1993@hotmail.com

4 Department of Chemistry, Faculty of Science, Cairo University, Giza 12613, Egypt

5 Department of Biology, Faculty of Science, Taibah University, Al-Madinah Al-Munawarah 30002, Saudi Arabia; nkaff@taibahu.edu.sa

6 Department of Chemistry, Faculty of Science, Islamic University of Madinah, Al-Madinah Al-Munawarah 42351, Saudi Arabia

* Correspondence: masaid@taibahu.edu.sa (M.A.S.); s.m.gomha@gmail.com (S.M.G.)

Citation: Abu-Melha, S.;

Edrees, M.M.; Said, M.A.;

Riyadh, S.M.; Al-Kaff, N.S.;

Gomha, S.M. Potential COVID-19

Drug Candidates Based on

Diazinyl-Thiazol-Imine Moieties:

Synthesis and Greener Pastures

Biological Study. Molecules 2022, 27,

488. https://doi.org/10.3390/

molecules27020488

Academic Editors: Isabella Rimoldi and Giorgio Facchetti

Received: 30 November 2021

Accepted: 28 December 2021

Published: 13 January 2022

Publisher's Note: MDPI stays neutral with regard to jurisdictional claims in published maps and institutional affiliations.

Copyright: (c) 2022 by the authors. Licensee MDPI, Basel, Switzerland. This article is an open access article distributed under the terms and conditions of the Creative Commons Attribution (CC BY) license (https:/ / creativecommons.org/licenses/by/ $4.0 /)$.

\begin{abstract}
A novel series of 1-aryl-N-[4-phenyl-5-(arylazo)thiazol-2-yl)methanimines has been synthesized via the condensation of 2-amino-4-phenyl-5-arylazothiazole with various aromatic aldehydes. The synthesized imines were characterized by spectroscopic techniques, namely ${ }^{1} \mathrm{H}$ and ${ }^{13} \mathrm{C}-\mathrm{NMR}$, FTIR, MS, and Elemental Analysis. A molecular comparative docking study for 3a-f was calculated, with reference to two approved drugs, Molnupiravir and Remdesivir, using 7BQY (M ${ }^{\text {pro; }}$ PDB code 7BQY; resolution: $1.7 \mathrm{~A}^{\circ}$ ) under identical conditions. The binding scores against 7BQY were in the range of -7.7 to $-8.7 \mathrm{kcal} / \mathrm{mol}$ for $3 \mathrm{a}-\mathrm{f}$. The high scores of the compounds indicated an enhanced binding affinity of the molecules to the receptor. This is due to the hydrophobic interactions and multihydrogen bonds between 3a-f ligands and the receptor's active amino acid residues. The main aim of using in silco molecular docking was to rank 3a-f with respect to the approved drugs, Molnupiravir and Remdesivir, using free energy methods as greener pastures. A further interesting comparison presented the laydown of the ligands before and after molecular docking. These results and other supporting statistical analyses suggested that ligands 3a-f deserve further investigation in the context of potential therapeutic agents for COVID-19. Free-cost, PASS, SwissADME, and Way2drug were used in this research paper to determine the possible biological activities and cytotoxicity of $\mathbf{3 a - f}$.
\end{abstract}

Keywords: imines-tethered thiazoles; synthesis; COVID-19; in silico molecular docking; molnupiravir; remdesivir; greener pastures

\section{Introduction}

Since the appearance of COVID-19, followed by the Delta variant and recently the potentially more infectious Omicron strain pandemic caused by severe acute respiratory syndrome, the world has taken action for protection, such as emphasizing the importance of social distancing/masking [1,2]. However, the virus is still spreading scarily and has caused extensive social, economic, and health disorders. Hence, efficient drugs are instantly needed to end this pandemic and help the society return to routine. The good news is that various COVID-19 vaccines have been developed and evaluated at an extraordinary speed [3-8]. Having this in view, in this paper, we will test and evaluate our compounds by comparing their performances to the two well-established drugs (Molnupiravir and 
Remdesivir). An in silco method will be employed as a preliminary study to filter and rank our compounds as greener pastures at this stage [9-11].

Furthermore, urgent needs for novel antimicrobial and anticancer agents have directed many researchers to design and synthesize a variety of bioactive heterocycles. Thiazoles are incorporated in most drugs such as Sulfathiazole (antimicrobial), Tiazofurin (antineoplastic), Ritonavir (antiretroviral), and Abafungin (antifungal) [12]. In addition, imine-containing azoles are highlighted to develop new potential drug candidates with diverse therapeutic efficacy such as anticancer, antibacterial, antifungal, antioxidant, antimicrobial, and antiproliferative activities [13-16]. Moreover, Schiff's bases have gained prominence role for antimicrobial, antituberculosis [17], anticonvulsant, antidepressant, analgesic, anti-inflammatory, antitumoral, vasodilator, and antiviral [18] activities. The synergism of thiazole with imine moiety in a hybridized molecule may result in increasing the biological potency, mainly because of the variation of substituents in the imine derivatives. Electron-donating and electron-withdrawing groups on arylazo moiety may affect biological activities. Promoted by the above observations, it was aimed to synthesize 1-aryl- $\mathrm{N}$-[4-phenyl-5-(arylazo)thiazol-2-yl)methanimines and evaluate their biological importance. It is important to mention here that we used 7BQY (M $\left.{ }^{\text {pro }}, \mathrm{PDB}\right)$ over 6LU7, because the crystal structure of the COVID-19 main protease in complex with the inhibitor, $\mathrm{N} 3$, has a resolution of $1.7 \AA$ whereas 6LU7 is with a resolution of $2.16 \AA$. Furthermore, this study aimed to rank the ligands with respect to two approved and widely used drugs.

\section{Results and Discussions}

The condensation reaction is an endeavor to synthesize imine compounds. Thus, the condensation of 2-amino-4-phenyl-5-arylazothiazole (1) with various aromatic aldehydes 2 in boiling ethanol and catalytic drops of piperidine resulted in the formation of the respective imine derivatives $3 \mathbf{a}-\mathbf{f}$, with electron-donating and electron-withdrawing groups on arylazo moiety (Scheme 1).
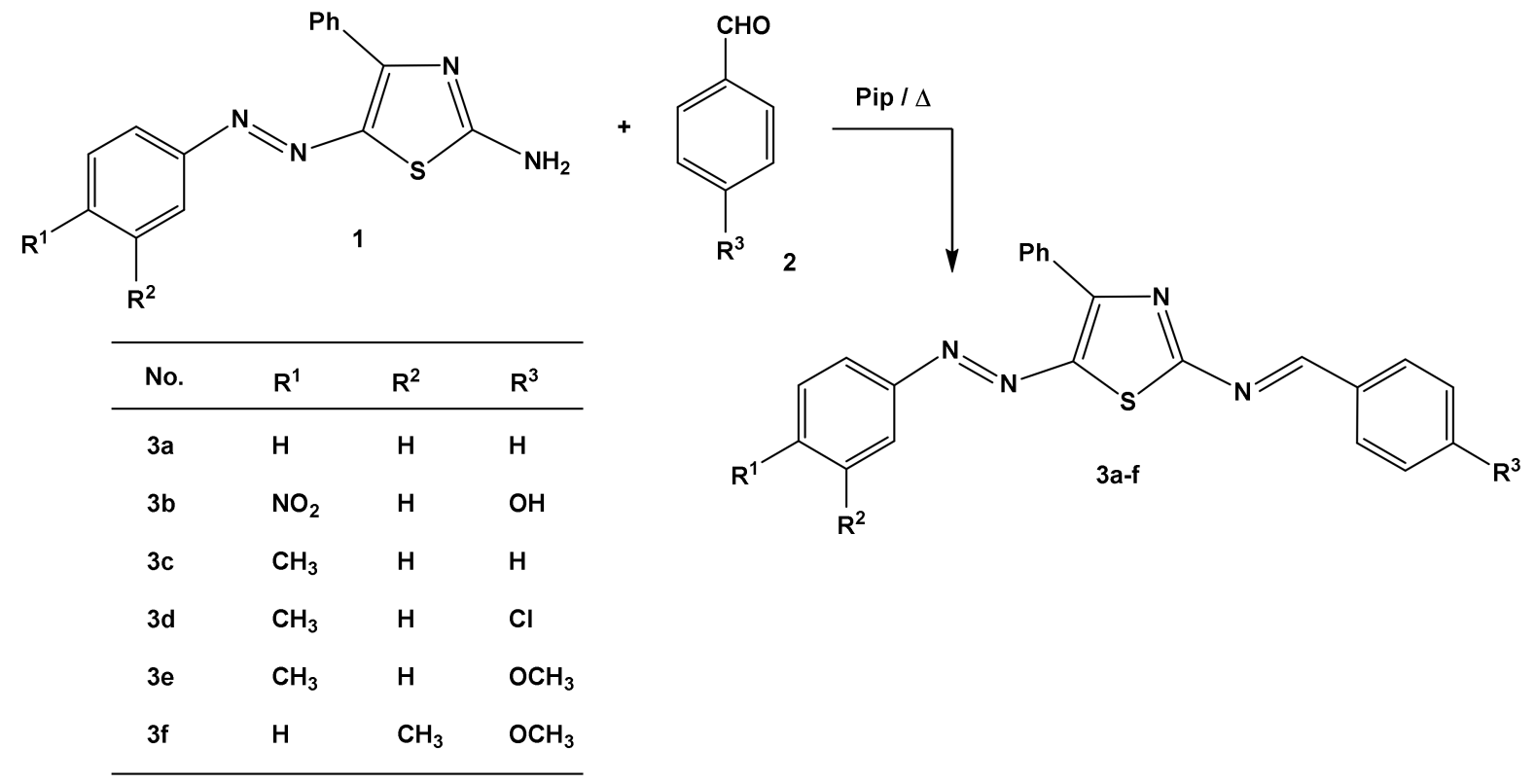

Scheme 1. Synthesis of arylazothiazolimines 3a-f.

The isolated products gave analytical data consistent with the imine structures. ${ }^{1} \mathrm{H}-$ NMR revealed one singlet signal at $\delta=(9.41-9.51)$ ppm due to $\mathrm{HC}=\mathrm{N}$ (Chart 1) [19]. The molecular ion peaks and microanalysis results were also in accordance with theoretical calculations for imine products. 


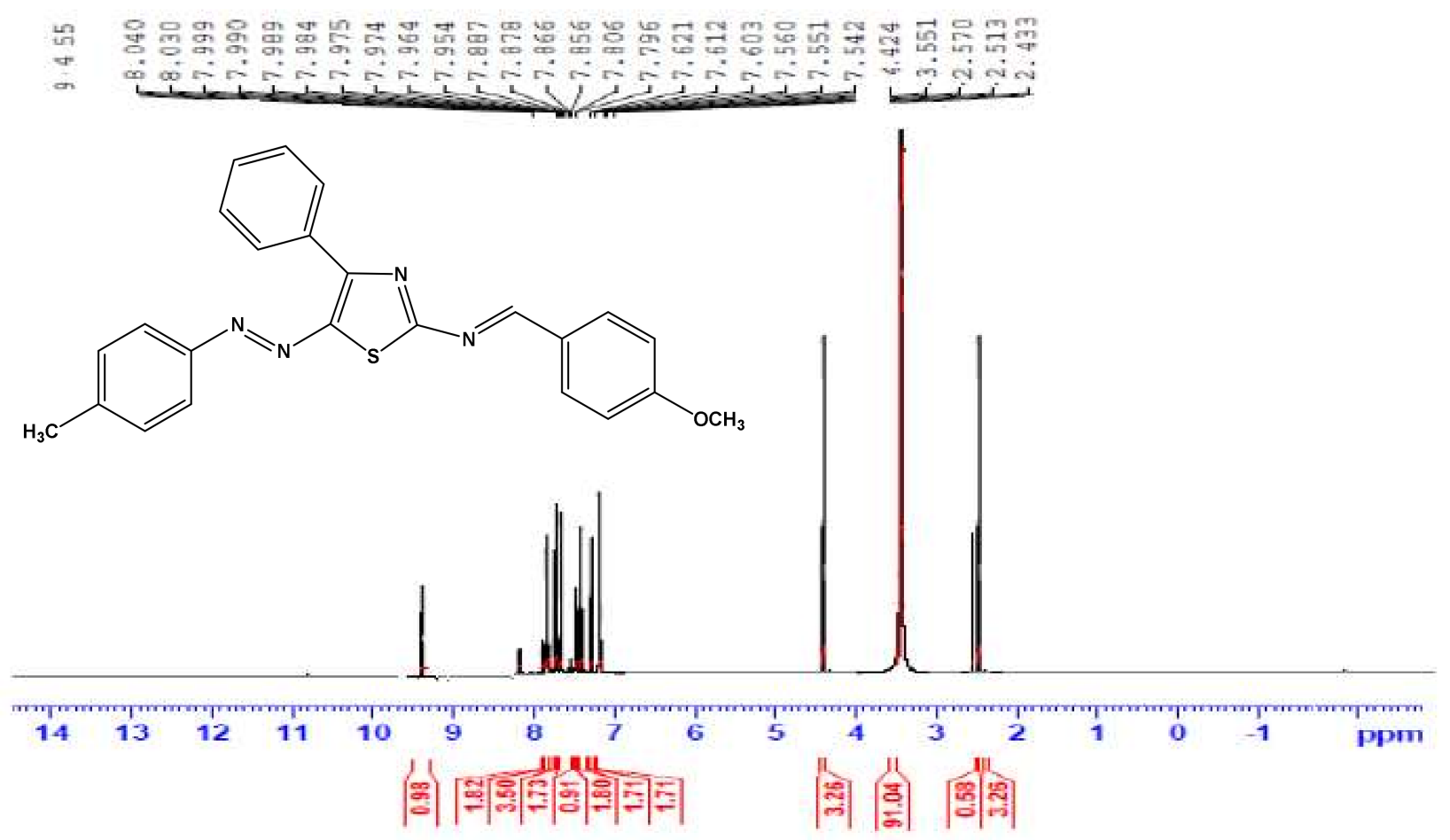

Chart 1. ${ }^{1} \mathrm{H}-\mathrm{NMR}$ of compound $\mathbf{3} \mathbf{e}$ as a representative example. More spectra are available on line as Supplementary Materials: Figure S1: IR of compound (3a), Figure S2: ${ }^{1} \mathrm{H}-\mathrm{NMR}$ of compound (3a), Figure S3: ${ }^{13} \mathrm{C}-\mathrm{NMR}$ of compound (3a), Figure S4: MS of compound (3a), Figure S5: IR of compound (3e), Figure S6: ${ }^{1} \mathrm{H}-\mathrm{NMR}$ of compound (3e), Figure S7: ${ }^{13} \mathrm{C}-\mathrm{NMR}$ of compound (3e), Figure S8: MS of compound (3e).

\subsection{Molecular Modeling against $7 B Q Y$}

The world is experiencing a tough time at many economic and social activities worldwide. It has been hit severely by COVID-19 and many variants, including the new Omicron variant [20-22]. Hence, we have been encouraged to study how ligands 3a-f might behave in the main protease's active site for COVID-19 ( $\mathrm{M}^{\mathrm{Pro}}$; PDB code: 7BQY) compared to the approved inhibitors, Molnupiravir and Remdesivir, in an effort to contribute to solving the outbreak of the pandemic disease. In this study, we preferred to use the 7BQY, because it has been docked against the well-known inhibitor N3 that appeared recently in Nature journal [23]. In addition, both the approved drugs are known to block the activity of RNA-dependent RNA polymerase (RdRp). However, they also affect viral replications through $\mathrm{M}^{\text {pro }}$ activity [24,25]. It is vital to be armed against viral protein to hinder its activities by inhibiting more than one of its proteins. Therefore, we carried out this study using a computer-assisted method to filter the compounds ahead to any in vivo and other experiments to minimize energy wastage following the recommendation from (COP26, in Glasgow on 31 October-13 November 2021). In actuality, computational science techniques and software are now at an excellent availability and an accuracy stage, making computational experiments more feasible than before for the drug design business. It is interesting to know that computer-aided drug designs have been in use for more than 40 years [26,27]. This study performed the binding affinities for ligands $3 a-f$ with 7BQY. In this computer-aided work, PyRx software (version 0.8) [28] considered 7BQY a flexible protein and 3a-f, Remdesivir, and Molnupiravir rigid ligands. However, the displays of the ligands before and after docking into 7BQY were not identical in all docking cases (Figure 1). For example, the $\mathrm{N}=\mathrm{N}$ bond in ligand 3a was oriented opposite to $3 \mathbf{a}$ in the protein cavity of 7BQY, which may be due to the H-bond with His164(A) (Figure 1), indicating ligand 3a after docking in the protein cavity did not stay the same as it was before docking. The superpositions of compounds 3a-f (color-coded), Molnupiravir, and Remdesivir (approved 
drugs by the FDA $[29,30])$ were docked against $7 \mathrm{BQY}$ using the same parameters for a comparison (Figure 2).
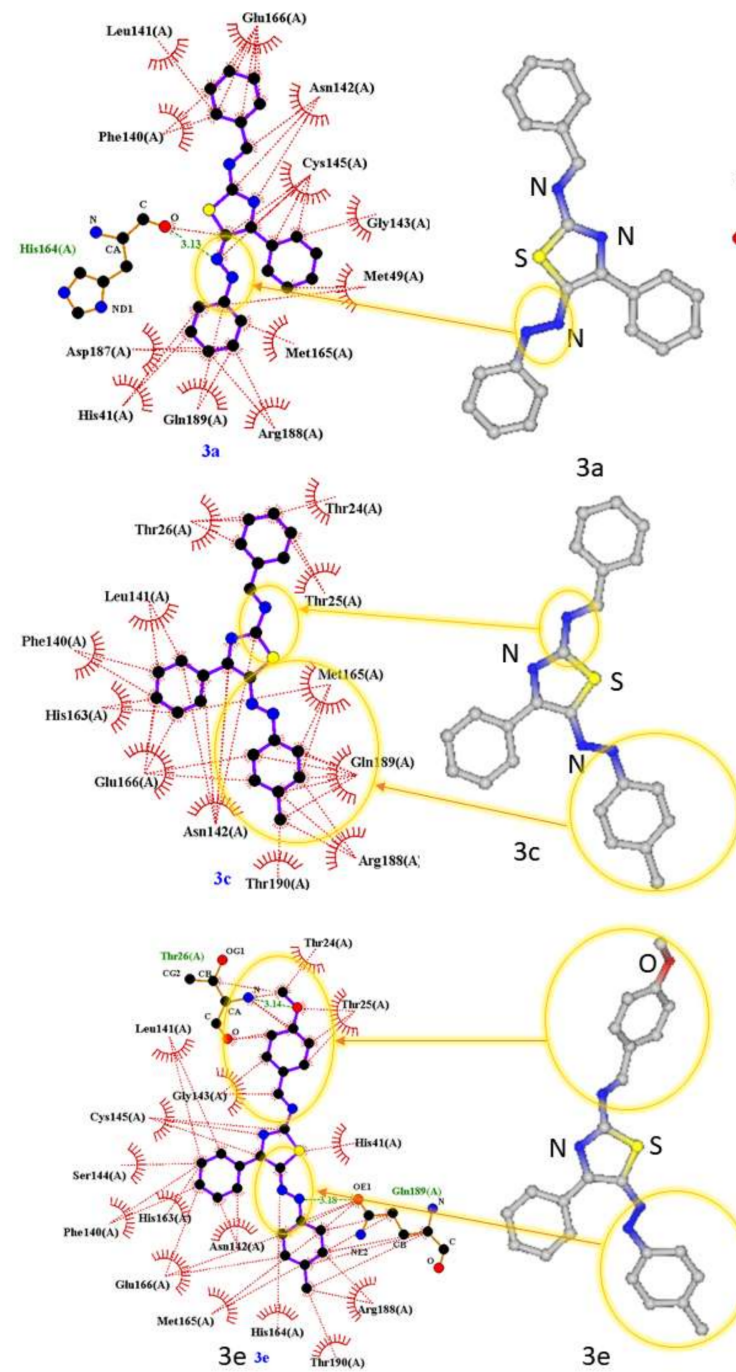

$3 e$ e

$3 e$

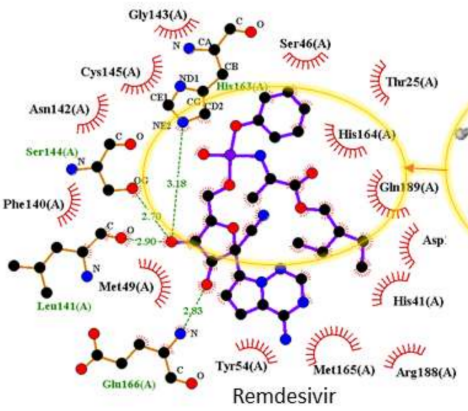

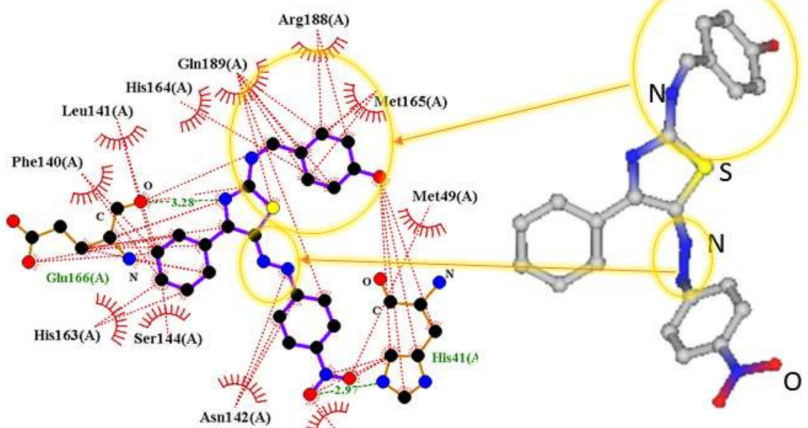

$3 \mathrm{~b} \quad \operatorname{Cys145(A)}$
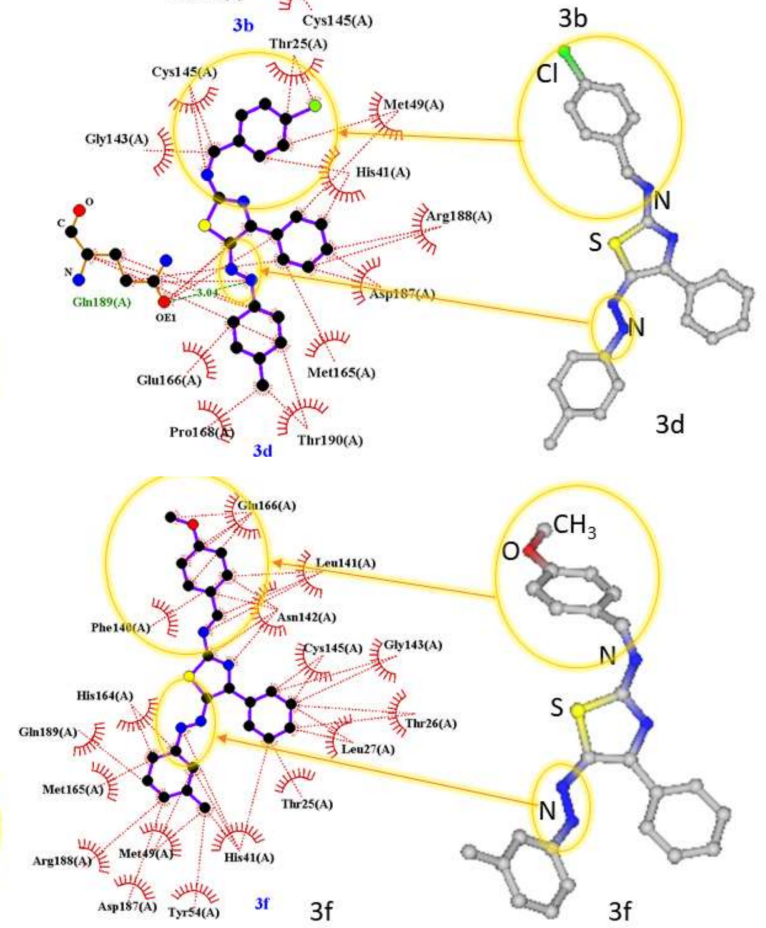

$3 f$

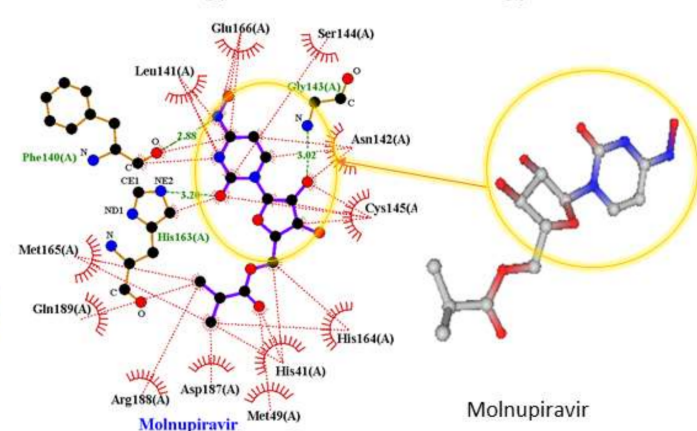

Figure 1. A schematic 2D LIGPLOT (LIGPLOT software is a program to generate schematic diagrams of protein-ligand interactions) representation showing 3a-f, Remdesivir, and Molnupiravir before and after docking into the binding pocket of 7BQY. The variations in the ligands are highlighted by yellow circles. 

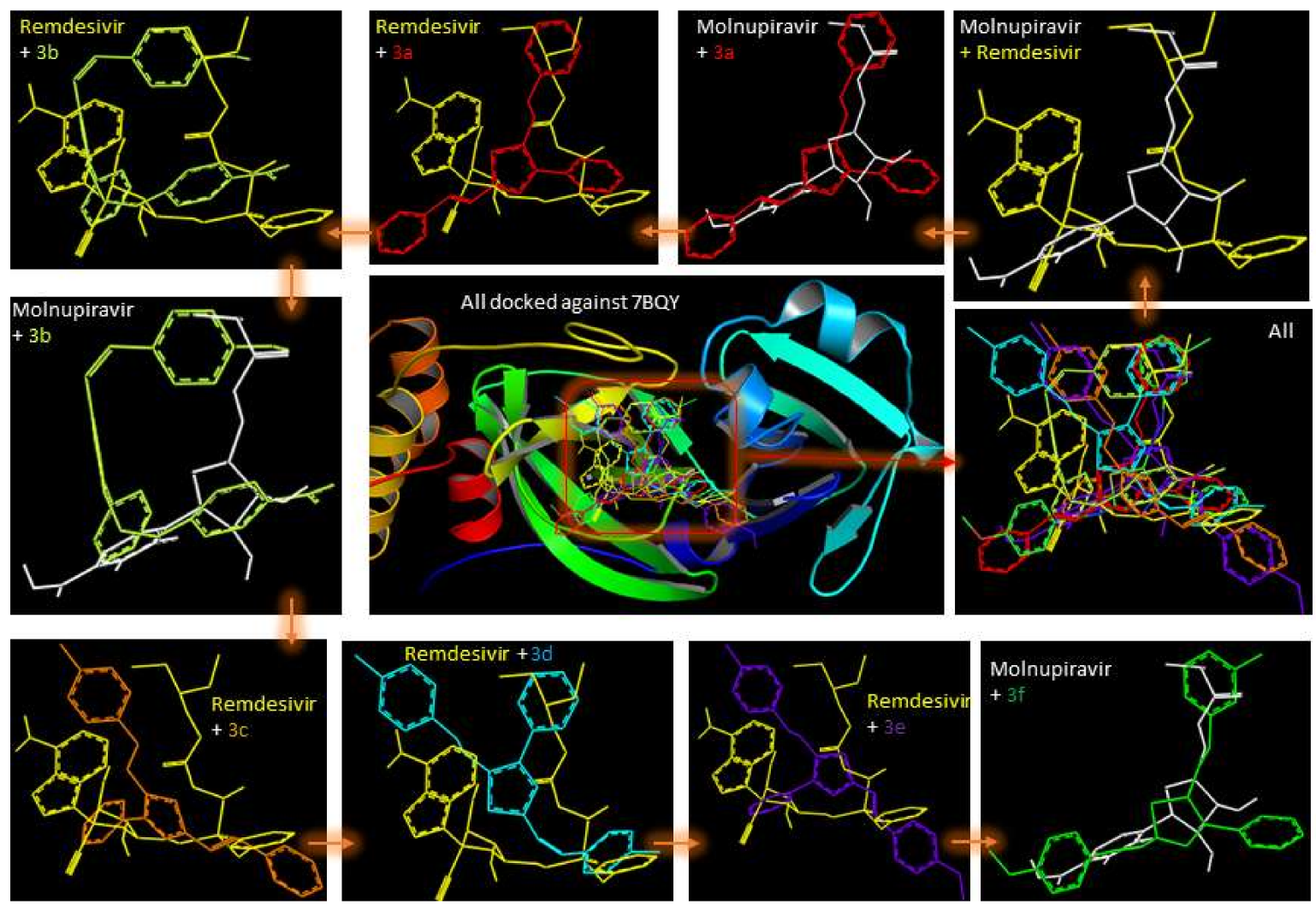

Figure 2. The superpositions of compounds $\mathbf{3 a}-\mathbf{f}$ and the approved drugs docked together into the binding pocket of 7BQY. Ligands, drugs, and labels are color-coded.

The results were represented by PyMOL [31] in the square frame (Figure 2). For the orientation comparison, each rectangular presents a ligand superimposed over either Remdesivir or Molnupiravir.

The superpositions revealed a close overlap between the ligands and either of the drugs in the protease site. Furthermore, the binding energies of Molnupiravir and Remdesivir were -7.0 and $-7.6 \mathrm{kcal} / \mathrm{mol}$, respectively. Compounds $\mathbf{3 a}-\mathbf{f}$ showed binding energies in a range of -7.7 and $-8.7 \mathrm{kcal} / \mathrm{mol}$, indicating possible similar biological activities to the two drugs $[32,33]$. This may suggest a further possible study of compounds $\mathbf{3 a}-\mathbf{f}$ in the context of a potential medicine for COVID-19 is recommended. The reason for choosing these approved drugs is that they are active against different viral diseases, including influenza [32]. It is essential to mention that all the docked molecules against the target enzyme COVID-19 were ranked according to their binding energies, shown in ascending order and color-coded molecules (Figure 3).

The binding affinity was attributed to many hydrogen bonds (green lines) and hydrophobic interactions (red lines) between ligands 3a-f and the receptor's active amino acid residues, as shown in Schematic 2D LIGPLOT (Figures 1 and 2). It could be seen that 3b formed two H-bonds with Glu166 and His41(A), whereas Molnupiravir formed three H-bonds with Phe140(A), His163(A), and Gly143(A), (Figure 4). Detailed key symbols can be found in a recent report [34]. 


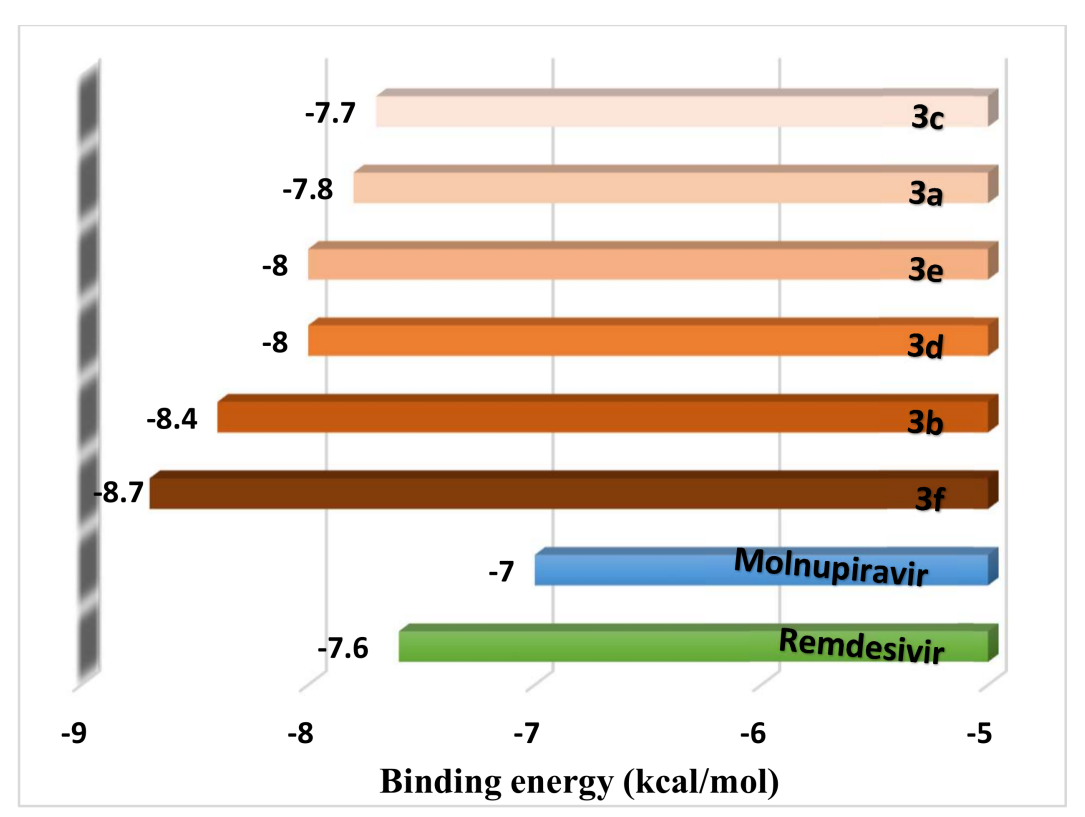

Figure 3. Binding affinities of compounds 3a-f against the COVID-19 protease 7BQY and the approved medicines for a comparison.
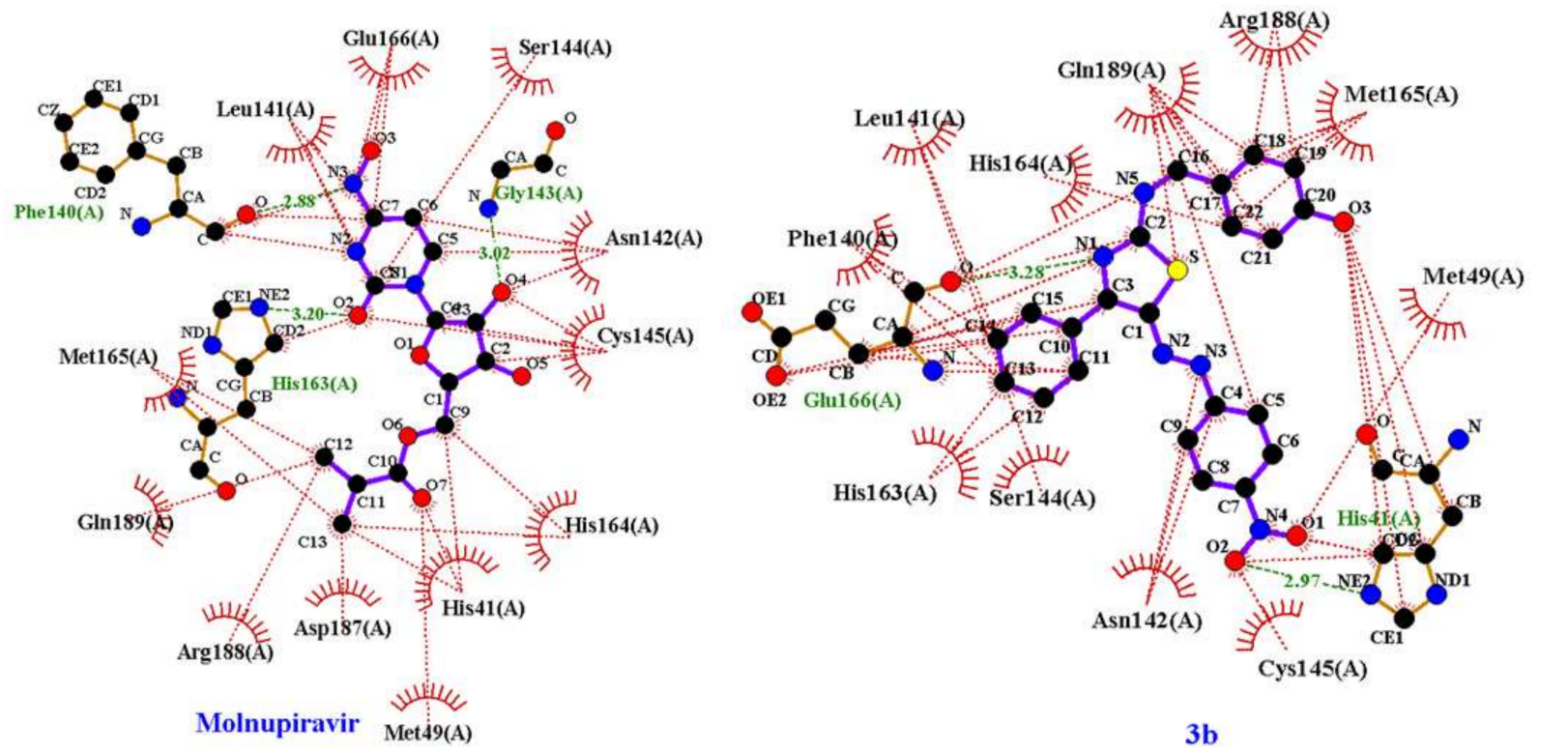

Figure 4. A schematic 2D LIGPLOT representation of Molnupiravir and $\mathbf{3 b}$ against the complex 7BQY showing the hydrogen and hydrophobic interactions.

All interactions were summarized for compounds $3 \mathbf{a}-\mathbf{f}$ and the approved drugs in Figure 5. 


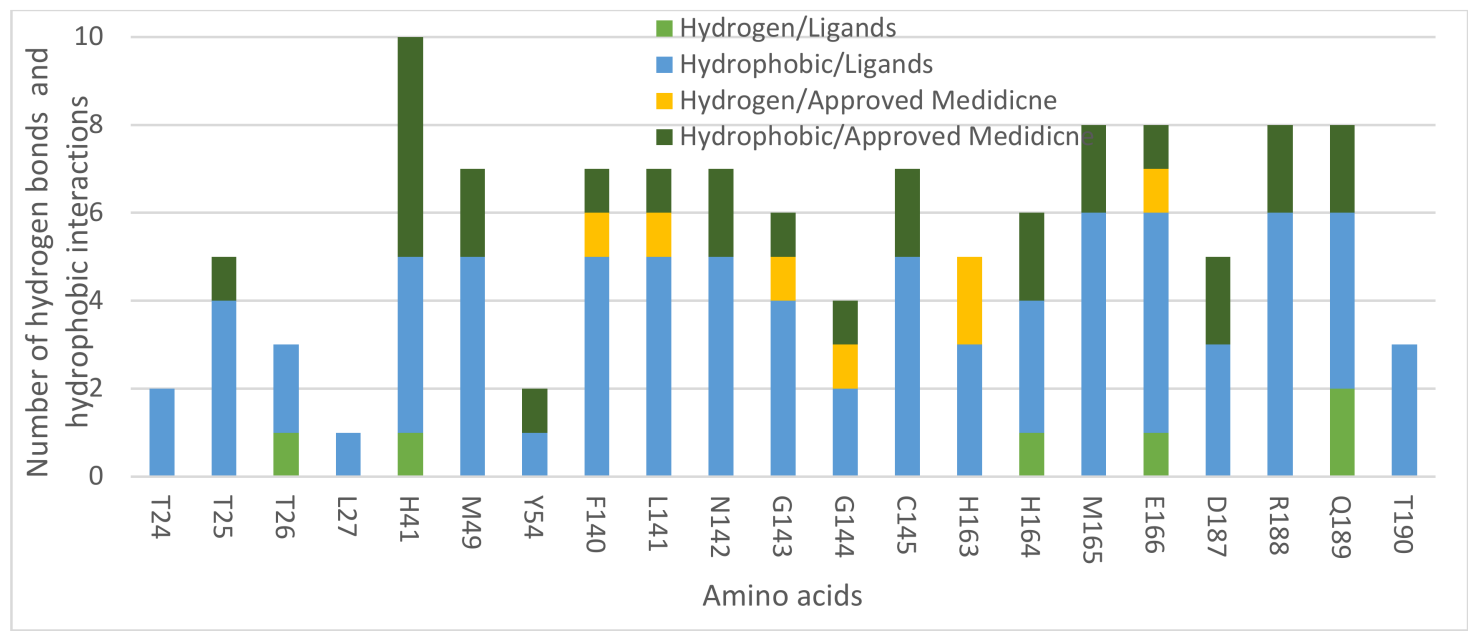

Figure 5. The numbers of hydrophobic interactions and H-bonds revealed upon docking 7BQY protease against compounds $\mathbf{3 a}-\mathbf{f}$ and the approved drugs.

The box plot produced with Minitab 19 presented the number of hydrogen and hydrophobic interactions between the amino acid residues of the $\mathrm{M}^{\text {pro }}$ substrate of COVID19 (7BQY) and compounds 3a-f in comparison to the two approved medicine. One of the approved drugs is already known and developed to treat Ebola virus cases infection by Gilead Sciences Inc., (Foster City, CA, USA) [35,36]. Recently, Molnupiravir [37] was approved to treat COVID-19 orally [38]. It is a broad-spectrum ribonucleoside inhibitor of RdRp RNA influenza and respiratory syncytial viruses such as COVID-19 [37].

The number of hydrogen bonds varied between the ligands $3 \mathbf{a}-\mathbf{f}$ and the two approved medicine docked with the COVID-19 $\mathrm{M}^{\text {pro }}$ pocket, with a mean of $0.29+1.34$ and $0.33+5.80$, respectively (Figure 5). The maximum number of hydrogen interactions was 2 in ligands 3a-f and 4 for the approved drugs (Figure 6). All compounds in this study displayed Hbonds. The hydrophobic interactions for the different amino acids varied between ligands 3a-f and the approved medicines (Figure 6). The minimum hydrophobic interactions were 0 for both, whereas the maximum hydrophobic interactions were 6 and 5 for ligands 3a-f and the approved medication, respectively (Figure 5).

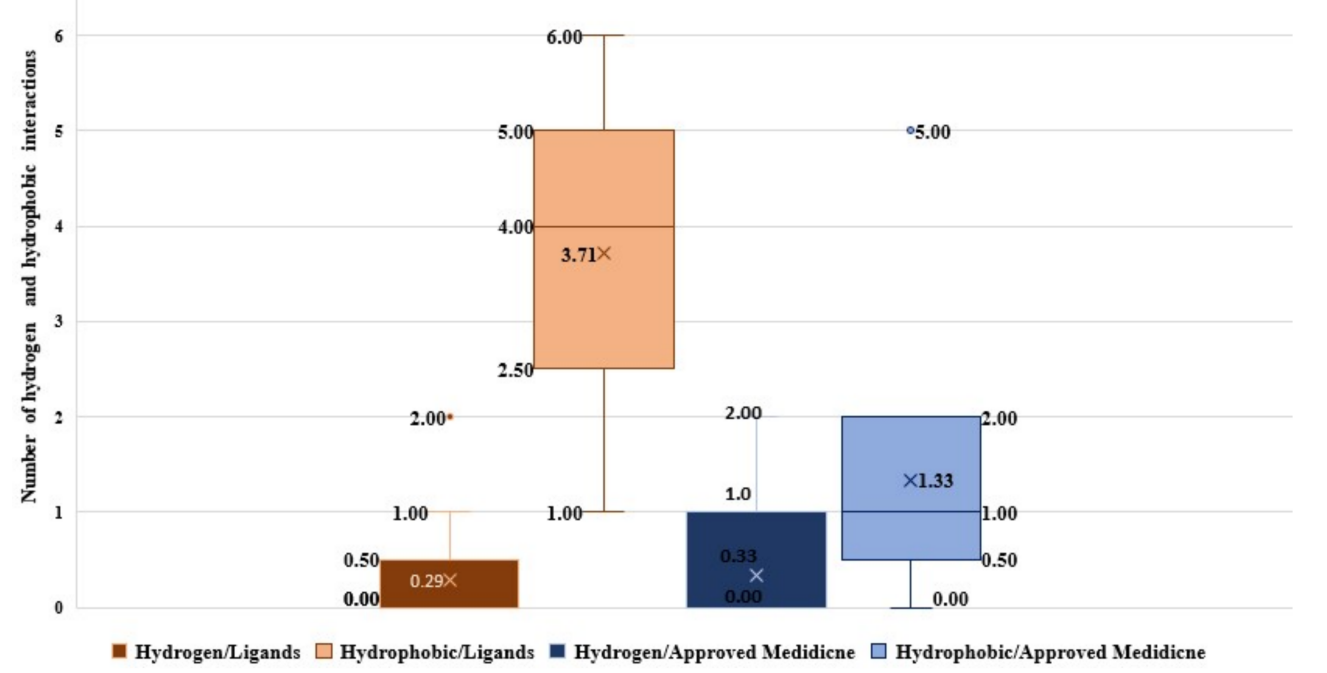

Figure 6. Box plot representing the comparison between hydrogen and hydrophobic bonds among the amino acid residues of the COVID-19 $\mathrm{M}^{\text {pro }}$ substrate-binding pocket produced by docking with the six newly synthesized ligands 3a-f, Remdesivir, and Molnupiravir. 
The nine docking poses of ligands 3a-f and the approved drugs Remdesivir and Molnupiravir showed an excellent fitting with the COVID-19 $\mathrm{M}^{\text {pro }}$ substrate pocket. The mean of the nine poses for each ligand was analyzed and compared using one-way ANOVA and Tukey's pairwise comparison. The binding affinity readings of the nine poses were significantly varied (Table 1).

Table 1. One-way ANOVA for the binding affinities of the 9 poses (pose 0 to pose 8 ).

\begin{tabular}{cccc}
\hline Source of Variance & DF & F-Value & $p$-Value \\
\hline Ligands and & 7 & 7.42 & 0.00 \\
approved drugs & 8 & 7.12 & 0.00 \\
Number of poses & & & \\
\hline
\end{tabular}

The variation was shown clearly in the interval plot, which demonstrated a negative relationship between the pose number and the binding affinity. The highest binding affinity was recorded for pose 0 , using the pooled STDEV of \pm 0.37 (Figure 7).

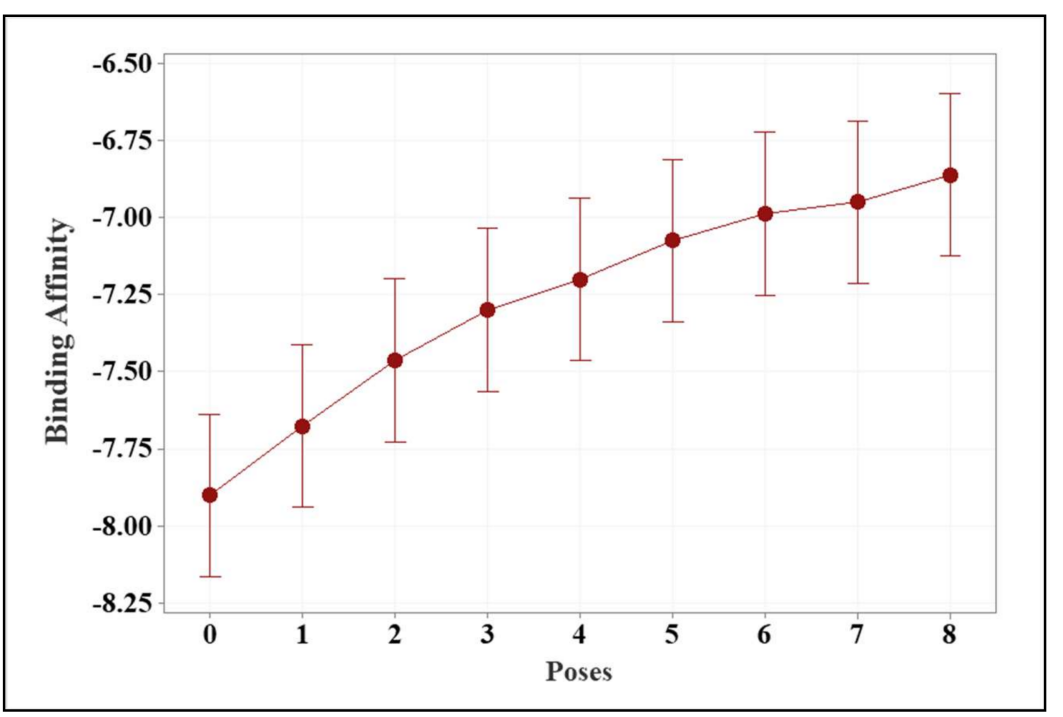

Figure 7. Interval plot of the binding affinities of the nine poses. The interval plots for the binding affinities of the synthesized ligands and the approved drugs were blotted for the interval calculated using a pooled standard division at a confidence level of $95 \%$.

Significant differences using ANOVA ( $p$-value) was 0.00 , which was lower than 0.05 (Table 1). The Tukey pairwise comparison analysis also showed the detailed variation of the binding affinity readings as a mean of those of the nine poses between the ligands and the approved drugs (Table 2 and Figure 7).

Compound $\mathbf{3 f}$ had the highest binding affinity with an average binding energy $(-7.81 \pm 0.48 \mathrm{kcal} / \mathrm{mol})$ with no significant differences at a $p$-value of 0.05 compared with other ligands, except $3 c$ and the approved drugs (Table 2). All the ligands recorded higher binding affinities than the approved drugs (Table 2). However, ligands $\mathbf{3 e}$ (average binding energy: $7.25 \pm 0.46 \mathrm{kcal} / \mathrm{mol}$ ) and $3 \mathrm{c}$ (average binding energy: $7.13 \pm 0.46 \mathrm{kcal} / \mathrm{mol}$ ), which had the lowest binding affinity in comparison with the other ligands, had no significant variation with Remdesivir and Molnupiravir (Table 2). 
Table 2. Means and SDs of the binding affinities of the nine docking poses for compounds against the COVID-19 main protease 7BQY.

\begin{tabular}{ccc}
\hline Ligand and Approved Medicines & $\begin{array}{c}\text { Average Binding Energy } \\
\text { (kcal/mol) }\end{array}$ \\
\hline & $3 \mathrm{f}$ & $-7.81 \pm 0.48^{\mathrm{a}}$ \\
Ligands & $3 \mathrm{~d}$ & $-7.52 \pm 0.21^{\mathrm{a}, \mathrm{b}}$ \\
& $3 \mathrm{a}$ & $-7.41 \pm 0.29^{\mathrm{a}, \mathrm{b}, \mathrm{c}}$ \\
& $3 \mathbf{b}$ & $-7.36 \pm 0.50^{\mathrm{a}, \mathrm{b}, \mathrm{c}}$ \\
& $3 \mathbf{e}$ & $-7.25 \pm 0.46^{\mathrm{a}, \mathrm{b}, \mathrm{c}, \mathrm{d}}$ \\
\hline \multirow{2}{*}{ Approved medicine } & $3 \mathbf{c}$ & $-7.13 \pm 0.46^{\mathrm{b}, \mathrm{c}, \mathrm{d}}$ \\
\hline $\begin{array}{l}\text { Notes: Different letters denote statistically significant differences using Tukey's multiple comparison test at } \\
p \leq 0.05 .\end{array}$ & $-6.93 \pm 0.33^{\mathrm{c}, \mathrm{d}}$ \\
\end{tabular}

\subsection{In Silico Toxicity Prediction for Compounds $\mathbf{3 a}-\mathbf{f}$}

The ProTox-II server used to detect toxicity of the synthesized compounds 3a-f. It predicts possible toxicity for a potential chemical to be used as a drug [29,30]. The results showed that the $\mathrm{LD}_{50}(\mathrm{mg} / \mathrm{kg})$ in parallel with the toxicity class for $\mathbf{3 a}-\mathbf{f}$ and the approved medicine as a comparison. Ligands $3 a-d$ were classified into toxic class 3 with $\mathrm{LD}_{50}(300 \mathrm{mg} / \mathrm{kg}$ ). Ligands $\mathbf{3 e}$ and $\mathbf{3 f}$ and the approved medicines (Remdesivir and Molnupiravir) were predicted to be under toxic class 4 with the first three having an $\mathrm{LD}_{50}$ of $1000 \mathrm{mg} / \mathrm{kg}$ and Molnupiravir having an $\mathrm{LD}_{50}$ of $826 \mathrm{mg} / \mathrm{kg}$. The average $\mathrm{LD}_{50}$ values, for the six ligands and the approved drugs, were similar $(43.51 \pm 1.60 \mathrm{mg} / \mathrm{kg})$. They all had the same prediction accuracy of $54.26 \%$ (Table 3 ).

Table 3. Acute oral toxicity predicted by the ProTox-II web server for ligands $3 a-f$ and the approved drugs.

\begin{tabular}{ccccc}
\hline Ligand & \multicolumn{4}{c}{ Oral Toxicity Prediction Results } \\
\cline { 2 - 5 } & $\begin{array}{c}\text { Predicted LD } \\
(\mathbf{m g} / \mathbf{k g})\end{array}$ & $\begin{array}{c}\text { Predicted } \\
\text { Toxicity Class }\end{array}$ & $\begin{array}{c}\text { Average } \\
\text { Similarity (\%) }\end{array}$ & $\begin{array}{c}\text { Prediction } \\
\text { Accuracy (\%) }\end{array}$ \\
\hline 3a & 300 & 3 & 44.61 & 54.26 \\
\hline 3b & 300 & 3 & 42.28 & 54.26 \\
\hline 3c & 300 & 3 & 44.32 & 54.26 \\
\hline 3d & 300 & 3 & 45.74 & 54.26 \\
\hline 3e & 1000 & 4 & 43.73 & 54.26 \\
\hline 3f & 1000 & 4 & 42.98 & 54.26 \\
\hline Molnupiravir & 1000 & 4 & 40.93 & 54.26 \\
\hline Remdesivir & 826 & 4 & 79.41 & 69.26 \\
\hline
\end{tabular}

The ProTox-II web server was used to predict organ toxicity (hepatotoxicity). Compounds $3 \mathbf{a}-\mathbf{f}$ and Molnupiravir were expected to have weak activities, behaving as toxic compounds to hepatot, but no activity was expected from Remdesivir. Ligand $\mathbf{3 b}$ was noticed to have the highest carcinogenic and mutagenic probabilities of 0.77 and 0.75 , respectively. However, ligand 3d, Molnupiravir, and Remdesivir were predicted to have no carcinogenic and mutagenic activity. Ligands $\mathbf{3 a}, \mathbf{3} \mathbf{c}, \mathbf{3 e}$, and $\mathbf{3 f}$ were found to have weak carcinogenic and mutagenic activities. All ligands, as well as the approved drugs, had no immunotoxicity with a probability of 0.99 . Interestingly, the ligands and the approved drugs behaved similarly with an average hepatotoxicity activity probability of $0.74+0.08$ (Table 4). 
Table 4. Organ toxicity and toxicological endpoints-predicted activity calculated using the ProTox-II web server for ligands $\mathbf{3 a - f}$, Molnupiravir, and Remdesivir.

\begin{tabular}{|c|c|c|c|c|c|c|c|c|c|c|}
\hline \multirow{2}{*}{ Ligands } & \multicolumn{2}{|c|}{ Hepatotoxicity } & \multicolumn{2}{|c|}{ Carcinogenicity } & \multicolumn{2}{|c|}{ Immunotoxicity } & \multicolumn{2}{|c|}{ Mutagenicity } & \multicolumn{2}{|c|}{ Cytotoxicity } \\
\hline & Activity & Probability & Activity & Probability & Activity & Probability & Activity & Probability & Activity & Probability \\
\hline $3 \mathbf{a}$ & Yes & 0.58 & Yes & 0.59 & No & 0.99 & Yes & 0.57 & No & 0.80 \\
\hline $3 b$ & Yes & 0.55 & Yes & 0.77 & No & 0.99 & Yes & 0.75 & No & 0.76 \\
\hline $3 c$ & Yes & 0.55 & Yes & 0.60 & No & 0.99 & Yes & 0.58 & No & 0.82 \\
\hline $3 d$ & Yes & 0.57 & No & 0.59 & No & 0.99 & No & 0.55 & No & 0.82 \\
\hline $3 e$ & Yes & 0.58 & Yes & 0.57 & No & 0.99 & Yes & 0.63 & No & 0.73 \\
\hline $3 f$ & Yes & 0.58 & Yes & 0.57 & No & 0.99 & Yes & 0.63 & No & 0.73 \\
\hline Molnupiravir & Yes & 0.56 & No & 0.50 & No & 0.96 & No & 0.50 & No & 0.74 \\
\hline Remdesivir & No & 0.56 & No & 0.55 & No & 0.90 & No & 0.62 & No & 0.55 \\
\hline
\end{tabular}

\subsection{Drug Likeness Evaluation}

SwissADME was used to predict the possibility of using ligands 3a-f as drugs by evaluating physicochemical properties, drug-likeness, and pharmacokinetics [39-41]. The same analysis was also carried out for Molnupiravir and Remdesivir. The physicochemical properties evaluated by ADMT included the molecular weight $(\mathrm{g} / \mathrm{mol})$, the molecular refractivity, and the topological polar surface area $\left(\AA^{2}\right)$. Table 5 summarizes the physiochemical properties, lipophilicity, and the drug-likeness evaluation. The molecular weight ranged between 368.45 and $429.45 \mathrm{~g} / \mathrm{mol}$ for the ligands, which was higher than that of Molnupiravir (329.31 g/mol) and lower than that of Remdesivir $(602.58 \mathrm{~g} / \mathrm{mol})$ (Table 5). All ligands, including Molnupiravir, had drug-likeness bioavailability ranging between 150 and $500 \mathrm{~g} / \mathrm{mol}$. The total surface area polarity (TSAP) was in the expected range of 20 and $130 \AA^{2}$. The TSAPs of most ligands $3 \mathbf{a}, 3 \mathbf{c}$, and $\mathbf{3} \mathbf{d}$ were $78.21 \AA^{2}$, and the TSAPs of 3e and $3 \mathbf{f}$ were also similar at $87.44 \AA^{2}$. However, the TSAP of $3 \mathbf{b}$ was $144.26 \AA^{2}$ closer to that of Molnupiravir (143.14 $\AA^{2}$ ), whereas Remdesivir showed the most significant value $\left(213.36 \AA^{2}\right)$. The solubility (H should not be higher than six for those molecules that might be used as drugs). Ligands $4-7$ had H-Bond acceptor (HBA). 3a, 3c, and $\mathbf{3 d}$ had four HBAs, $\mathbf{3 e}$ and $\mathbf{3 b}$ had five HBAs, and $\mathbf{3 b}$ had seven HBAs. All ligands $\mathbf{3 a}-\mathbf{c}$ had lower HBAs than Molnupiravir and Remdesivir, which were 8 and 12, respectively.

Table 5. Physicochemical properties and lipophilicity of ligands 3a-f in comparison with the approved drugs Molnupiravir and Remdesivir.

\begin{tabular}{|c|c|c|c|c|c|c|c|c|}
\hline Physicochemical & $3 a$ & $3 b$ & $3 c$ & $3 d$ & $3 e$ & $3 f$ & Molnupiravir & Remdesivir \\
\hline Molecular weight (g/mol) & 368.45 & 429.45 & 382.48 & 416.93 & 412.51 & 412.51 & 329.31 & 602.58 \\
\hline Heavy atom & 27 & 31 & 28 & 29 & 30 & 30 & 23 & 42 \\
\hline Arom. heavy atom & 23 & 23 & 23 & 23 & 23 & 23 & 6 & 15 \\
\hline Fraction Csp3 & 0.00 & 0.00 & 0.04 & 0.04 & 0.08 & 0.08 & 0.62 & 0.48 \\
\hline Rotatable bond & 5 & 6 & 5 & 5 & 6 & 6 & 6 & 14 \\
\hline H-bond acceptor & 4 & 7 & 4 & 4 & 5 & 5 & 8 & 12 \\
\hline H-bond donor & 0 & 1 & 0 & 0 & 0 & 0 & 4 & 4 \\
\hline Molar refractivity & 111.86 & 122.71 & 116.83 & 121.84 & 123.32 & 123.32 & 76.02 & 150.43 \\
\hline Polar surface area $\left(\AA^{2}\right)$ & 78.21 & 144.26 & 78.21 & 78.21 & 87.44 & 87.44 & 143.14 & 213.36 \\
\hline \multicolumn{9}{|l|}{ Lipophilicity } \\
\hline MLOGP & 4.05 & 2.57 & 4.27 & 4.74 & 3.92 & 3.92 & -1.15 & 0.18 \\
\hline WLOGP & 6.98 & 6.59 & 7.28 & 7.94 & 7.29 & 7.29 & -1.65 & 2.21 \\
\hline XLOGP3 & 6.36 & 5.83 & 6.72 & 7.35 & 6.69 & 6.69 & -1.34 & 1.91 \\
\hline \multicolumn{9}{|l|}{ Drug-likeness evaluation } \\
\hline Lipinski & 0 & 0 & 1 & 1 & 0 & 0 & 0 & 2 \\
\hline
\end{tabular}


The bioavailability radar of the six ligands was drawn based on the physicochemical properties, lipophilicity, size, polarity, solubility, unsaturation, and flexibility (Figure 8). The optimal range of these properties is pink, whereas the red line represents ligands and approved drugs properties. As shown in Figure 8, all ligands fell entirely for size, polarity, and flexibility, except $\mathbf{3 b}$ which was slightly out for polarity. All the six ligands were slightly out for polarity and solubility; however, they were all out for the unsaturation fractions property (Figure 8). Molnupiravir was entirely in the pink area and slightly out for polarity like $\mathbf{3 b}$. Thus, the bioavailability radar for Remdesivir showed that it fell in the red area at lipophilicity, solubility, and unsaturation. It is out of the other three- properties size, polarity, and flexibility. The six ligands fulfilled some properties of drug-likeness, but not all. All ligands, except $\mathbf{3 b}$, were predicated to be orally bioavailable and flexible with a suitable size (Figure 8). SwissADME was also used to evaluate the pharmacokinetics properties of ligands 3a-f. There was no P-glycoprotein (P-gp) substrate for all of them, except $\mathbf{3 b}$ and Remdesivir, justifying their good intestinal absorption. The bioavailability exhibited low gastrointestinal (GI) absorption and the blood-brain barrier (BBB) permeant for all of them, including both medicines (Table 6). The study's components interacted with one or two isoenzymes of the cytochrome P (CYP) family, confirming their better effectiveness with little toxicity, which was most similar to Molnupiravir (Table 6).

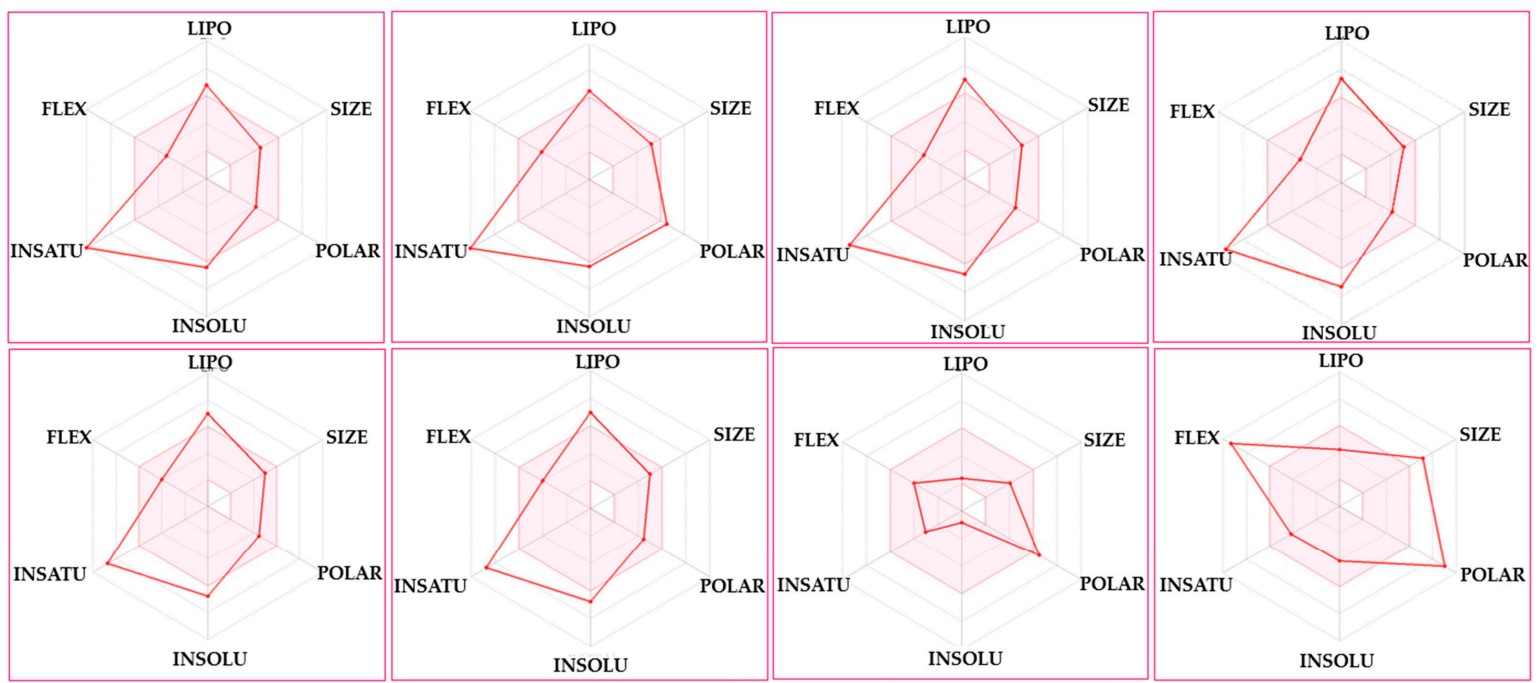

Figure 8. Bioavailability radar for ligands $3 \mathbf{a}-\mathbf{f}$ and the approved drugs Molnupiravir and Remdesivir.

Importantly, when applying the Lipinski rule of five (ROF5), i.e., a molecular weight of $<500 \mathrm{~g} / \mathrm{mol}$, a $\log \mathrm{P}$ value of $<5$, the number of $\mathrm{H}$-bond donors of $<5$, the number of $\mathrm{H}$-bond acceptors of $<10$ [42], and an additional rule proposed by Veber concerning the number of the rotatable bonds of $<10$ [43], all the six ligands were likely to be bioavailable as drugs. However, some were better than others when summing oral bioavailability rules, toxicity, and docking. For example, $3 \mathrm{f}$ had the highest binding affinity when docked to the M $\mathrm{M}^{\text {ro }}$ of SARS-CoV-2, and it also met the ROF5. This can also be applied to the other ligands; thus, the poorest ligand was $3 \mathbf{c}$, with the lowest binding affinity in its docking and the least extent to which it met the ROF5. 
Table 6. The pharmacokinetics properties of ligands 3a-f in comparison with those of the approved drugs, Molnupiravir and Remdesivir.

\begin{tabular}{|c|c|c|c|c|c|c|c|c|c|}
\hline \multicolumn{2}{|c|}{ Pharmacokinetics } & $3 a$ & $3 b$ & $3 c$ & $3 d$ & $3 e$ & $3 f$ & Molnupiravir & Remdesivir \\
\hline \multicolumn{2}{|c|}{ Gastrointestinal (GI) absorption } & Low & Low & Low & Low & Low & Low & Low & Low \\
\hline \multicolumn{2}{|c|}{ Blood-brain barrier (BBB) permeant } & No & No & No & No & No & No & No & No \\
\hline \multicolumn{2}{|c|}{ P-glycoprotein (P-gp) substrate } & No & No & No & Yes & No & No & No & Yes \\
\hline \multirow{5}{*}{ Inhibitor } & CYP1A2 & Yes & No & No & No & No & No & No & No \\
\hline & CYP2C19 & Yes & No & Yes & No & No & No & No & No \\
\hline & CYP2C9 & Yes & Yes & Yes & No & Yes & Yes & Yes & No \\
\hline & CYP2D6 & No & No & No & No & No & No & No & No \\
\hline & CYP3A4 & No & No & No & No & No & No & No & Yes \\
\hline
\end{tabular}

\section{Materials and Methods}

The requisite starting materials such as acetophenone, iodine, and thiourea used to prepare 2-amino-4-phenylthiazoles [44-46] were procured from Sigma-Aldrich without any further purification. All the solvents were purified and dried by a standard method.

\subsection{Instruments}

An electrothermal Gallenkamp apparatus was operated to measure the melting points for the newly synthesized compounds. A Pye-Unicam SP300 instrument in potassium bromide discs was used to measure IR spectra. A Varian Mercury VXR-300 spectrometer (300 MHz for ${ }^{1} \mathrm{H}-\mathrm{NMR}$ and $75 \mathrm{MHz}$ for ${ }^{13} \mathrm{C}-\mathrm{NMR}$ ) was manipulated to measure the ${ }^{1} \mathrm{H}$ NMR and ${ }^{13} \mathrm{C}-\mathrm{NMR}$ spectra, and the chemical shifts were related to those of the solvent. GCMS-Q1000-EX Shimadzu and GCMS 5988-A HP spectrometers were used to record the mass spectra of the samples at an ionizing voltage of $70 \mathrm{eV}$. Elemental analyses were carried out at the Microanalytical Centre of Cairo University, Giza, Egypt.

\subsection{Synthesis of 2-Amino-4-phenyl-5-arylazothiazoles}

A cold solution of 2-amino-4-phenylthiazoles (5 mmol) in ethanol (30 mL), buffered with sodium acetate trihydrate, was added to the aryldiazonium chloride prepared by diazotizing appropriate aromatic amines such as aniline, 4-nitroaniline, 4-toluidine, and 3-toluidine dissolved in concentrated hydrochloric acid $(6 \mathrm{~N}, 2 \mathrm{~mL})$ with a sodium nitrite solution $(0.07 \mathrm{~g}, 1 \mathrm{mmol})$ in water $(2 \mathrm{~mL})$ [44-46]. The addition was carried out portion-wise with stirring at $0-5{ }^{\circ} \mathrm{C}$ for $30 \mathrm{~min}$. After the complete addition, the reaction mixture was stirred for a further $4 \mathrm{~h}$ at room temperature, then kept in a refrigerator for $12 \mathrm{~h}$ and finally diluted with water. The precipitated solid was collected by filtration, washed with water, dried and finally recrystallized from ethanol to afford the corresponding 2-amino-4-phenyl5-arylazothiazoles (1) [44-46].

\subsection{General Procedure for the Synthesis of Compounds 3a-f}

A solution of 2-amino-4-phenyl-5-arylazothiazole (1) (1 mmol of each) in ethanol containing aromatic aldehydes $(1 \mathrm{mmol})$ and a few drops of piperidine was refluxed for $3 \mathrm{~h}$ and then left to cool. The crude product was collected by filtration and recrystallized from ethanol to generate compounds $3 \mathbf{a}-\mathbf{f}$.

1-Phenyl-N-[4-phenyl-5-(phenylazo)thiazol-2-yl)methanimine (3a), Dark red crystals (0.31 g, $85 \%) ; \mathrm{mp} 195-197^{\circ} \mathrm{C}$; IR (KBr) $v=1610(\mathrm{C}=\mathrm{N}), 1445(\mathrm{~N}=\mathrm{N}), \mathrm{cm}^{-1} ;{ }^{1} \mathrm{H}-\mathrm{NMR}\left(\mathrm{DMSO}-d_{6}\right.$, $300 \mathrm{MHz}): \delta=7.31-8.32(15 \mathrm{H}, \mathrm{m}, \mathrm{Ar}-\mathrm{H}), 9.41(1 \mathrm{H}, \mathrm{s}, \mathrm{CH}=) ;{ }^{13} \mathrm{C}-\mathrm{NMR}\left(\mathrm{DMSO}-d_{6}, 75 \mathrm{MHz}\right)$ : $\delta=120.3,126.1,126.9,128.1,128.7,128.9,129.2,129.7,130.9,131.4,132.9,133.4,135.3,140.6$, 142.4, 170.3; EIMS m/z (\%): 368 [M $\mathrm{M}^{+}$(50), 105 (100), 77 (80). Anal. calcd for $\mathrm{C}_{22} \mathrm{H}_{16} \mathrm{~N}_{4} \mathrm{~S}$ (368.11): C, 71.72; H, 4.38; N, 15.21; S, 8.70. Found: C, 71.66; H, 4.28; N, 15.32; S, 8.64.

1-(4-Hydroxyphenyl)-N-[4-phenyl-5-((4-nitrophenyl)azo)thiazol-2-yl)methanimine (3b), Brown powder $(0.34 \mathrm{~g}, 80 \%) ; \operatorname{mp} 212-214{ }^{\circ} \mathrm{C}$; IR $(\mathrm{KBr}) v=1602(\mathrm{C}=\mathrm{N}), 1446(\mathrm{~N}=\mathrm{N}), \mathrm{cm}^{-1}{ }^{1} \mathrm{H}-\mathrm{NMR}$ 
(DMSO- $\left.d_{6}, 300 \mathrm{MHz}\right): \delta=7.31-7.99(13 \mathrm{H}, \mathrm{m}, \mathrm{Ar}-\mathrm{H}), 9.42(1 \mathrm{H}, \mathrm{s}, \mathrm{CH}=), 12.31(1 \mathrm{H}, \mathrm{s}, \mathrm{OH})$; ${ }^{13} \mathrm{C}-\mathrm{NMR}\left(\mathrm{DMSO}-d_{6}, 75 \mathrm{MHz}\right): \delta=120.4,126.1,126.6,126.7,128.1,128.2,128.9,129.1,132.1$, 133.4, 134.9, 135.3, 138.3, 140.2, 149.4, 166.1; EIMS m/z (\%): 429 [M $\left.{ }^{+}\right]$(20), 105 (100), 77 (60). Anal. calcd for $\mathrm{C}_{22} \mathrm{H}_{15} \mathrm{~N}_{5} \mathrm{O}_{3} \mathrm{~S}$ (429.09): C, 61.53; H, 3.52; N, 16.31; S, 7.47. Found: C, 61.66; $\mathrm{H}, 3.38 ; \mathrm{N}, 16.42 ; \mathrm{S}, 7.62$.

1-Phenyl-N-[4-phenyl-5-((4-methylphenyl)azo)thiazol-2-yl)methanimine (3c), Brown pow$\operatorname{der}(0.32 \mathrm{~g}, 84 \%) ; \operatorname{mp} 150-152{ }^{\circ} \mathrm{C}$; IR $(\mathrm{KBr}) v=1600(\mathrm{C}=\mathrm{N}), 1447(\mathrm{~N}=\mathrm{N}), \mathrm{cm}^{-1} ;{ }^{1} \mathrm{H}-\mathrm{NMR}$ $\left(\mathrm{DMSO}-d_{6}, 300 \mathrm{MHz}\right): \delta=2.32\left(3 \mathrm{H}, \mathrm{s}, \mathrm{Ar}-\mathrm{CH}_{3}\right), 7.35-8.01(14 \mathrm{H}, \mathrm{m}, \mathrm{Ar}-\mathrm{H}), 9.49(1 \mathrm{H}, \mathrm{s}, \mathrm{CH}=)$; ${ }^{13} \mathrm{C}-\mathrm{NMR}\left(\mathrm{DMSO}-d_{6}, 75 \mathrm{MHz}\right): \delta=16.9\left(\mathrm{CH}_{3}\right), 116.5 .120 .3,126.6,126.2,128.4,128.9,129.2$, 129.7, 132.1, 132.4, 132.9, 133.4, 139.3, 140.6, 142.4, 166.3; EIMS m/z (\%): 382 [M $\left.{ }^{+}\right]$(10), 105 (100), 77 (80). Anal. calcd for $\mathrm{C}_{23} \mathrm{H}_{18} \mathrm{~N}_{4} \mathrm{~S}$ (382.13): C, 72.23; H, 4.74; N, 14.65; S, 8.38. Found: C, 72.36; H, 4.68; N, 14.42; S, 8.56.

1-(4-Chlorophenyl)-N-[4-phenyl-5-((4-methylphenyl)azo)thiazol-2-yl)methanimine (3d), Brown powder $(0.33 \mathrm{~g}, 80 \%)$; mp $165-167^{\circ} \mathrm{C}$; IR (KBr) $v=1612(\mathrm{C}=\mathrm{N}), 1456(\mathrm{~N}=\mathrm{N}), \mathrm{cm}^{-1}{ }^{1}{ }^{1} \mathrm{H}-\mathrm{NMR}$ $\left(\mathrm{DMSO}-d_{6}, 300 \mathrm{MHz}\right): \delta=2.42\left(3 \mathrm{H}, \mathrm{s}, \mathrm{Ar}-\mathrm{CH}_{3}\right), 7.41-8.48(13 \mathrm{H}, \mathrm{m}, \mathrm{Ar}-\mathrm{H}), 9.51(1 \mathrm{H}, \mathrm{s}, \mathrm{CH}=)$; ${ }^{13} \mathrm{C}-\mathrm{NMR}$ (DMSO- $\left.d_{6}, 75 \mathrm{MHz}\right): \delta=16.3\left(\mathrm{CH}_{3}\right), 113.9,121.8,125.4,126.3,127.1,128.9,129.1$, 130.7, 130.8, 137.4, 137.9, 139.3, 141.3, 144.2, 150.4, 164.1; EIMS m/z (\%): 416 [M $\left.{ }^{+}\right]$(10), 105 (60), 77 (100). Anal. calcd for $\mathrm{C}_{23} \mathrm{H}_{17} \mathrm{ClN}_{4} \mathrm{~S}$ (416.09): C, 66.26; H, 4.11; N, 13.44; S, 7.69. Found: C, 61.36; H, 4.28; N, 13.52; S, 7.62.

1-(4-Methoxyphenyl)-N-[4-phenyl-5-((4-methylphenyl)azo)thiazol-2-yl)methanimine (3e), Brown powder $(0.31 \mathrm{~g}, 75 \%)$; mp $173-175{ }^{\circ} \mathrm{C}$; IR $(\mathrm{KBr}) v=1600(\mathrm{C}=\mathrm{N}), 1456(\mathrm{~N}=\mathrm{N}), \mathrm{cm}^{-1}$; ${ }^{1} \mathrm{H}-\mathrm{NMR}\left(\mathrm{DMSO}-d_{6}, 300 \mathrm{MHz}\right): \delta=2.44\left(3 \mathrm{H}, \mathrm{s}, \mathrm{Ar}-\mathrm{CH}_{3}\right), 4.42\left(3 \mathrm{H}, \mathrm{s}, \mathrm{OCH}_{3}\right), 7.54-8.07(13 \mathrm{H}$, $\mathrm{m}, \mathrm{Ar}-\mathrm{H}), 9.46(1 \mathrm{H}, \mathrm{s}, \mathrm{CH}=) ;{ }^{13} \mathrm{C}-\mathrm{NMR}\left(\mathrm{DMSO}-d_{6}, 75 \mathrm{MHz}\right): \delta=15.8\left(\mathrm{CH}_{3}\right), 66.2\left(\mathrm{OCH}_{3}\right)$, $119.8,120.3,123.9,126.3,127.5,128.9,129.4,130.7,132.8,134.1,135.4,138.1,139.3,141.3$, 143.6, 166.1; EIMS $m / z$ (\%): $412\left[\mathrm{M}^{+}\right]$(10), 105 (100), 77 (50). Anal. calcd for $\mathrm{C}_{24} \mathrm{H}_{20} \mathrm{~N}_{4} \mathrm{OS}$ (412.14): C, 69.88; H, 4.89; N, 13.58; S, 7.77. Found: C, 70.06; H, 4.99; N, 13.72; S, 7.92.

1-(4-Methoxyphenyl)-N-[4-phenyl-5-((3-methylphenyl)azo)thiazol-2-yl)methanimine (3f), Brown powder $(0.31 \mathrm{~g}, 75 \%) ; \operatorname{mp} 222-224^{\circ} \mathrm{C}$; IR $(\mathrm{KBr}) v=1600(\mathrm{C}=\mathrm{N}), 1457(\mathrm{~N}=\mathrm{N}), \mathrm{cm}^{-1}$; ${ }^{1} \mathrm{H}-\mathrm{NMR}\left(\mathrm{DMSO}-d_{6}, 300 \mathrm{MHz}\right): \delta=2.42\left(3 \mathrm{H}, \mathrm{s}, \mathrm{Ar}-\mathrm{CH}_{3}\right), 4.47\left(3 \mathrm{H}, \mathrm{s}, \mathrm{OCH}_{3}\right), 7.30-8.06$ $(13 \mathrm{H}, \mathrm{m}, \mathrm{Ar}-\mathrm{H}), 9.49(1 \mathrm{H}, \mathrm{s}, \mathrm{CH}=) ;{ }^{13} \mathrm{C}-\mathrm{NMR}\left(\mathrm{DMSO}-d_{6}, 75 \mathrm{MHz}\right): \delta=15.6\left(\mathrm{CH}_{3}\right), 63.8$ $\left(\mathrm{OCH}_{3}\right), 114.6,116.5,120.1,120.3,127.9,128.3,128.5,128.9,129.4,131.7,132.2,132.5,132.8$, 135.4, 139.5, 140.3, 143.6, 166.1; EIMS m/z (\%): 412 [M $\left.{ }^{+}\right](10), 105$ (100), 77 (70). Anal. calcd for $\mathrm{C}_{24} \mathrm{H}_{20} \mathrm{~N}_{4} \mathrm{OS}$ (412.14): C, 69.88; H, 4.89; N, 13.58; S, 7.77. Found: C, 70.09; H, 4.73; N, 13.33; S, 7.58 .

\subsection{Docking In Silico Studies}

The docking calculations of compounds 3a-f, Molnupiravir, and Remdesivir using 7BQY (Mpro, PDB code: 7BQY; resolution: $1.7 \AA$ ) were accomplished using the Autodock Vina wizard in PyRx 0.8. [47]. Settings were made identical for docking in this research study: grid box center_x $=5.37343529609$, center_y $=0.301235653306$, center_z $=23.0783947527$, size_ $x=19.9069566462$, size_y $=23.5833091318$, and size_z $=25.0$. The remaining parameters were used as a default setting in the Autodock Vina-PyRx. All drugs and ligands were converted to the SDF file type using Chem. The draw program was used as an input to Autodock vina in PyRx. Energy minimization parameters used for all ligands in this study, before docking were as following: force field = uff; optimization algorithm $=$ conjugate gradients; total number of steps $=200$; number of steps $=1$; stop if the energy difference is less than 0.1 . The proteases (PDB code: 7BQY) were saved in the PDB format after deleting the water molecules and ligands using Discovery Studio Visualizer v17.2.0.16349. The PyMOL molecular viewer was used to present the output data [29]. The schematic diagrams of protein-ligand interactions were generated using the LIGPLOT program [48]. 


\subsection{Statistical Analysis}

Analysis of variance of one factor (one-way ANOVA) was used as a statistical model to evaluate the binding affinities of both the synthesized ligands (3a-f) and the two approved drugs, Molnupiravir and Remdesivir. In addition, Tukey pairwise comparison was applied following one-way ANOVA analysis to group means considering $p$ of $\leq 0.05$ as a statistically significant level. ANOVA statistical analyses were carried out using Minitab 19 (www.minitab.com, accessed on 6 November 2021). Boxplot analysis was carried using Excel in Microsoft Office.

\subsection{In Silico Toxicity Prediction}

In silico methods and the ProTox-II platform was used to predict the toxicity levels of the ligands synthesized in this study, which were compared to those of the approved drugs Molnupiravir and Remdesivir [29,30]. The ProTox-II system has five classification steps: (1) acute toxicity (oral toxicity model and six toxicity classes); (2) organ toxicity with one model; (3) toxicological endpoints with four models; (4) toxicological pathways with 12 models; and (5) toxicity targets with 15 models. A total of 33 models were used in this prediction process allowing the prediction for various toxicity endpoints such as hepatotoxicity, cytotoxicity, carcinogenicity, mutagenicity, and immunotoxicity. The Acute oral toxicity predictions for substances were classified into different toxicity classes, depending upon the $\mathrm{LD}_{50}(\mathrm{mg} / \mathrm{kg}$ body weight). These classes were the same class as in the Globally Harmonized System (GHS) classification and labeling of chemicals. These classes were as following: class 1 -fatal if swallowed $\left(\mathrm{LD}_{50} \leq 5 \mathrm{mg} / \mathrm{kg}\right)$; class 2-fatal if swallowed ( $5 \mathrm{mg} / \mathrm{kg}<\mathrm{LD}_{50} \leq 50 \mathrm{mg} / \mathrm{kg}$ ); class 3-toxic if swallowed $\left(50 \mathrm{mg} / \mathrm{kg}<\mathrm{LD}_{50} \leq 300 \mathrm{mg} / \mathrm{kg}\right)$; class 4 -harmful if swallowed $\left(300 \mathrm{mg} / \mathrm{kg}<\mathrm{LD}_{50} \leq\right.$ $2000 \mathrm{mg} / \mathrm{kg})$; class $5-$ may be harmful if swallowed $\left(2000 \mathrm{mg} / \mathrm{kg}<\mathrm{LD}_{50} \leq 5000 \mathrm{mg} / \mathrm{kg}\right)$. The average and SD were calculated when needed.

\subsection{Swiss ADME Drug-Likeness Properties Prediction}

The pharmacokinetic and drug-like properties of the selected compounds were evaluated using SwissADME (absorption, distribution, metabolism, and excretion) descriptors by a SwissADME online server (http:/ / www.swissadme.ch/, accessed on 22 December 2021 as previously reported [39].

\section{Conclusions}

A straightforward procedure was employed to obtain 1-aryl- $\mathrm{N}$-[4-phenyl-5-(arylazo)thiazol2-yl)methanimines (3a-f) in a reasonable high yield. A molecular comparative docking study for 3a-f was calculated with reference to two approved drugs, Molnupiravir and Remdesivir, using 7BQY ( $\mathrm{M}^{\text {pro }}$, PDB code: 7BQY; resolution: $1.7 \AA$ ) under identical conditions and using minimum energy towards greener pastures. The results showed more negative (more negative is better) binding scores for $\mathbf{3 a}-\mathbf{f}$ than for Molnupiravir and Remdesivir. The high scores of 3a-f indicated a better fit of the ligands in the receptor's active amino acid residues of 7BQY. However, the increased binding score was not enough to judge the compounds' suitability as inhibitors for COVID-19. However, the superpositions of the ligands with respect to the approved drugs, Molnupiravir and Remdesivir, uncovered similar behaviors of both in the amino acid cavity of 7BQY. PASS and Way2drug cytotoxicity tools were used to reveal that $\mathbf{3 d}$ was the same as Molnupiravir, suggesting a need for a further study in the context of potential therapeutic agents for COVID-19. Further analysis using SwissADME was performed to show that the six ligands were likely to be bioavailable drugs.

Supplementary Materials: Figure S1: IR of compound (3a), Figure S2: ${ }^{1} \mathrm{H}-\mathrm{NMR}$ of compound (3a), Figure S3: ${ }^{13} \mathrm{C}-\mathrm{NMR}$ of compound (3a), Figure S4: MS of compound (3a), Figure S5: IR of compound (3e), Figure S6: ${ }^{1} \mathrm{H}-\mathrm{NMR}$ of compound (3e), Figure S7: ${ }^{13} \mathrm{C}-\mathrm{NMR}$ of compound (3e), Figure S8: MS of compound (3e). 
Author Contributions: Conceptualization, S.A.-M., M.M.E., M.A.S., S.M.R., N.S.A.-K., S.M.G.; Methodology, M.M.E., project administration, S.A.-M.; writing-original draft, S.M.R., M.A.S., N.S.A.-K. All authors have read and agreed to the published version of the manuscript.

Funding: Deanship of Scientific Research at King Khalid University for funding this work through a General Research Project under grant number R.G.P.1/205/41.

Institutional Review Board Statement: Not applicable.

Informed Consent Statement: Not applicable.

Data Availability Statement: The Supplementary Data has been in a separate sheet.

Acknowledgments: The authors extend their appreciation to the Deanship of Scientific Research at King Khalid University for funding this work. Musa A Said is thankful to AvH, Germany.

Conflicts of Interest: The authors declare no conflict of interest.

Sample Availability: Samples of the compounds are available from the authors.

\section{References}

1. Borbone, N.; Piccialli, G.; Roviello, G.N.; Oliviero, G. Nucleoside Analogs and Nucleoside Precursors as Drugs in the Fight against SARS-CoV-2 and Other Coronaviruses. Molecules 2021, 26, 986. [CrossRef]

2. $\quad$ Singh, T.U.; Parida, S.; Lingaraju, M.C.; Manickam, K.; Kumar, D.; Singh, R.K. Drug repurposing approach to fight COVID-19. Pharmacol. Rep. 2020, 72, 1479-1508. [CrossRef]

3. Gao, Z.; Xu, Y.; Sun, C.; Wang, X.; Guo, Y.; Qiu, S.; Ma, K. A systematic review of asymptomatic infections with COVID-19. J. Microbiol. Immunol. Infect. 2021, 54, 12-16. [CrossRef]

4. Yüce, M.; Filiztekin, E.; Özkaya, K.G. COVID-19 diagnosis-A review of current methods. Biosens. Bioelectron. 2021, 172, 112752. [CrossRef]

5. Li, Y.; Tenchov, R.; Smoot, J.; Liu, C.; Watkins, S.; Zhou, Q. A Comprehensive Review of the Global Efforts on COVID-19 Vaccine Development. ACS Cent. Sci. 2021, 7, 512-533. [CrossRef]

6. Noor, R. A Review on the Effectivity of the Current COVID-19 Drugs and Vaccines: Are They Really Working Against the Severe Acute Respiratory Syndrome Coronavirus 2 (SARS-CoV-2) Variants? Curr. Clin. Microbiol. Rep. 2021, 8, 186-193. [CrossRef]

7. Costanzo, M.; De Giglio, M.A.R.; Roviello, G. Anti-Coronavirus Vaccines: Past Investigations on SARS-CoV-1 and MERS-CoV, the Approved Vaccines from BioNTech/Pfizer, Moderna, Oxford/AstraZeneca and others under Development Against SARS-CoV-2 Infection. Curr. Med. Chem. 2021, in press. [CrossRef]

8. Sultana, J.; Mazzaglia, G.; Luxi, N.; Cancellieri, A.; Capuano, A.; Ferrajolo, C.; de-Waure, C.; Ferlazzo, G.; Trifiro, G. Potential effects of vaccinations on the prevention of COVID-19: Rationale, clinical evidence, risks, and public health considerations. Exp. Rev. Vacc. 2020, 19, 919-936. [CrossRef]

9. Germain, R.N.; Meier-Schellersheim, M.; Nita-Lazar, A.; Fraser, I.D.C. Systems biology in immunology: A computational modeling perspective. Annu. Rev. Immunol. 2011, 29, 527-585. [CrossRef]

10. Roviello, G.; Roviello, V.; Autiero, I.; Saviano, M. Solid phase synthesis of TyrT, a thymine-tyrosine conjugate with poly(A) RNA-binding ability. RCS Adv. 2016, 6, 27607-27613. [CrossRef]

11. Afzal, O.; Kumar, S.; Haider, M.R.; Ali, M.R.; Kumar, R.; Jaggi, M.; Bawa, S. A review on anticancer potential of bioactive heterocycle quinoline. Eur. J. Med. Chem. 2015, 97, 871-910. [CrossRef]

12. Ali, S.H.; Sayed, A.R. Review of the synthesis and biological activity of thiazoles. Synth. Commun. 2021, 51, 670-700. [CrossRef]

13. Altamimi, M.A.; Hussain, A.; Alshehri, S.; Imam, S.S.; Alnami, A.; Bari, A. Novel hemocompatible imine compounds as alternatives for antimicrobial therapy in pharmaceutical application. Processes 2020, 8, 1476. [CrossRef]

14. Bashiri, M.; Jarrahpour, A.; Rastegari, B.; Iraji, A.; Irajie, C.; Amirghofran, Z.; Malek-Hosseini, S.; Motamedifar, M.; Haddadi, M.; Zomorodian, K.; et al. Synthesis and evaluation of biological activities of tripodal imines and $\beta$-lactams attached to the 1,3,5-triazine nucleus. Monatsh. Chem. 2020, 151, 821-835. [CrossRef]

15. Da Silva, E.T.; Araújo, A.S.; Moraes, A.M.; de Souza, L.A.; Lourenço, M.C.S.; de Souza, M.V.N.; Wardell, J.L.; Wardell, S.M.S.V. Synthesis and Biological Activities of Camphor Hydrazone and Imine Derivatives. Sci. Pharm. 2016, 84, 467. [CrossRef]

16. Sakthinathan, S.P.; Suresh, R.; Kamalakkannan, D.; Mala, V.; Sathiyamoorthi, K.; Vanangamudi, G.; Thirunarayanan, G. Microwave assisted synthesis, spectral correlation and antimicrobial Evaluation of some aryl imines. J. Chil. Chem. Soc. 2018, 63, 3918-3923.

17. Khan, M.S.; Siddiqui, S.P.; Tarannum, N. A systematic review on the synthesis and biological activity of hydrazide derivatives. Hygeia. J. Drugs Med. 2017, 9, 61-79. [CrossRef]

18. Jeelani, A.; Muthu, S.; Narayana, B. Molecular structure determination, Bioactivity score, Spectroscopic and Quantum computational studies on (E)-N'-(4-Chlorobenzylidene)-2-(napthalen-2-yloxy) acetohydrazide. J. Mol. Struct. 2021, 1241, 130558. [CrossRef]

19. Alsaygh, A.; Al-Humaidi, J.; Al-Najjar, I. Synthesis of Some New Pyridine-2-yl-Benzylidene-Imines. Int. J. Org. Chem. 2014, 4, 116-121. [CrossRef] 
20. Donnelly, R.; Patrinos, H.A. Learning loss during COVID-19: An early systematic review. Prospects 2021, 1-9. [CrossRef]

21. Marin, B.G.; Aghagoli, G.; Lavine, K.; Yang, L.; Siff, E.J.; Chiang, S.S.; Salazar-Mather, T.P.; Dumenco, L.; Savaria, M.C.; Aung, S.N.; et al. Predictors of COVID-19 severity: A literature review. Rev. Med. Virol. 2021, 31, 1-10. [CrossRef]

22. Zhang, X.; Tan, Y.; Ling, Y.; Lu, G.; Liu, F.; Yi, Z.; Jia, X.; Wu, M.; Shi, B.; Xu, S.; et al. Viral and host factors related to the clinical outcome of COVID-19. Nature 2020, 583, 437-440. [CrossRef]

23. Jin, Z.; Du, X.; Xu, Y.; Deng, Y.; Liu, M.; Zhao, Y.; Zhang, B.; Li, X.; Zhang, L.; Peng, C.; et al. Structure of Mpro from SARS-CoV-2 and discovery of its inhibitors. Nature 2020,582, 289-293. [CrossRef]

24. Vallianou, N.G.; Tsilingiris, D.; Christodoulatos, G.S.; Karampela, I.; Dalamaga, M. Anti-viral treatment for SARS-CoV-2 infection: A race against time amidst the ongoing pandemic. Metab. Open 2021, 10, 100096. [CrossRef]

25. Nguyen, H.L.; Thai, N.Q.; Truong, D.T.; Li, M.S. Remdesivir Strongly Binds to Both RNA-Dependent RNA Polymerase and Main Protease of SARS-CoV-2: Evidence from Molecular Simulations. J. Phys. Chem. B 2020, 124, 11337-11348. [CrossRef]

26. Van Gunsteren, W.F.; Karplus, M. Protein Dynamics in Solution and in a Crystalline Environment: A Molecular Dynamics Study. Biochemistry 1982, 21, 2259-2274. [CrossRef]

27. Musumeci, D.; Ullah, S.; Ikram, A.; Roviello, G.N. Novel insights on nucleopeptide binding: A spectroscopic and In Silico investigation on the interaction of a thymine-bearing tetrapeptide with a homoadenine DNA. J. Mol. Liq. 2021, 117975. [CrossRef]

28. Wolinski, K.; Hinton, J.F.; Wishart, D.S.; Sykes, B.D.; Richards, F.M.; Pastone, A.; Hayes, D.M. Hyper Chem Version 8.pdf PYRX, USA 2001. Available online: http:/ / www.swissadme.ch/ (accessed on 22 December 2021).

29. Drwal, M.N.; Banerjee, P.; Dunkel, M.; Wettig, M.R.; Preissner, R. ProTox: A web server for the in-silico prediction of rodent oral toxicity. Nucleic Acids Res. 2014, 42, W53-W58. [CrossRef]

30. Banerjee, P.; Eckert, A.O.; Schrey, A.K.; Preissner, R. ProTox-II: A webserver for the prediction of toxicity of chemicals. Nucleic Acids Res. 2018, 46, W257-W263. [CrossRef]

31. DeLano, W.L. PyMOL Reference Guide; Delano Scientific: San Carlos, CA, USA, 2004; pp. 1-68.

32. Rubin, D.; Chan-Tack, K.; Farley, J.; Sherwat, A. FDA Approval of Remdesivir-A Step in the Right Direction. N. Engl. J. Med. 2020, 383, 2598-2600. [CrossRef]

33. Shah, B.; Modi, P.; Sagar, S.R. In silico studies on therapeutic agents for COVID-19: Drug repurposing approach. Life Sci. 2020, 252, 117652. [CrossRef]

34. Alsafi, M.A.; Hughes, D.L.; Said, M.A. First COVID-19 molecular docking with a chalcone-based compound: Synthesis, singlecrystal structure and Hirshfeld surface analysis study. Acta Crystallogr. Sect. C Struct. Chem. 2020, 76, 1043-1050. [CrossRef]

35. Imran, M.; Alshrari, A.S.; Asdaq, S.M.B.; Abida. Trends in the development of remdesivir based inventions against COVID-19 and other disorders: A patent review. J. Infect. Public Health 2021, 14, 1075-1086. [CrossRef]

36. Pardo, J.; Shukla, A.M.; Chamarthi, G.; Gupte, A. The journey of remdesivir: From Ebola to COVID-19. Drugs Context 2020, 9 , 4-14. [CrossRef]

37. Yoon, J.J.; Toots, M.; Lee, S.; Lee, M.E.; Ludeke, B.; Luczo, J.M.; Ganti, K.; Cox, R.M.; Sticher, Z.M.; Edpuganti, V.; et al. Orally Efficacious Broad-Spectrum Ribonucleoside Analog Inhibitor of Influenza and Respiratory Syncytial Viruses. Antimicrob. Agents Chemother. 2018, 62, e00766-18. [CrossRef]

38. Fischer, W.; Eron, J.J.; Holman, W.; Cohen, M.S.; Fang, L.; Szewczyk, L.J.; Sheahan, T.P.; Baric, R.; Mollan, K.R.; Wolfe, C.R.; et al Molnupiravir, an Oral Antiviral Treatment for COVID-19. Preprint. medRxiv 2021. [CrossRef]

39. Daina, A.; Michielin, O.; Zoete, V. SwissADME: A free web tool to evaluate pharmacokinetics, druglikeness and medicinal chemistry friendliness of small molecules. Sci. Rep. 2017, 7, 42717. [CrossRef]

40. Parlak, C.; Alver, Ö.; Ouma, C.N.M.; Rhyman, L.; Ramasami, P. Interaction between favipiravir and hydroxychloroquine and their combined drug assessment: In silico investigations. Chem. Pap. 2021, in press. [CrossRef]

41. Ritchie, T.J.; Ertl, P.; Lewis, R. The graphical representation of ADME-related molecule properties for medicinal chemists. Drug Discov. Today 2011, 16, 65-72. [CrossRef]

42. Lipinski, C.A.; Lombardo, F.; Dominy, B.W.; Feeney, P.J. Experimental and computational approaches to estimate solubility and permeability in drug discovery and development settings. Adv. Drug Deliv. Rev. 2001, 46, 3-26. [CrossRef]

43. Veber, D.F.; Johnson, S.R.; Cheng, H.-Y.; Smith, B.R.; Ward, K.W.; Kopple, K.D. Molecular Properties That Influence the Oral Bioavailability of Drug Candidates. J. Med. Chem. 2002, 45, 2615-2623. [CrossRef]

44. Yen, M.S. Synthesis and solvatochromism of heterocyclic bichromophoric dyes derived from 2-aminothiazole. Pigment. Resin Tech 2012, 41, 216-222. [CrossRef]

45. Derkowska-Zielinska, B.; Skowronski, L.; Biitseva, A.; Grabowski, A.; Naparty, M.K.; Smokal, V.; Kysil, A.; Krupka, O. Optical characterization of heterocyclic azo dyes containing polymers thin films. Appl. Surf. Sci. 2017, 421, 361-366. [CrossRef]

46. Prajapati, A.K.; Modi, V.P. Synthesis and biological activity of n-\{5-(4-methylphenyl) diazenyl-4-phenyl-1, 3-thiazol-2yl\}benzamide derivatives. Quim. Nova 2011, 34, 771-774. [CrossRef]

47. Trott, O.; Olson, A.J. AutoDock Vina: Improving the speed and accuracy of docking with a new scoring function, efficient optimisation, and multithreading. J. Comput. Chem. 2009, 31, 455-461. [CrossRef]

48. Wallace, A.C.; Laskowski, R.A.; Thornton, J.M. Ligplot: A program to generate schematic diagrams of protein-ligand interactions. Protein Eng. Des. Sel. 1995, 8, 127-134. [CrossRef] 